\title{
Alleviation of thermoregulatory responses of Baladi Does by chromium and Selenium-E supplementation in subtropical areas.
}

\author{
Eid $^{1}$ S. Y., El-Sayed ${ }^{2}$ A. I. M., Farghaly ${ }^{1}$ H. A. M. and El-Tarabany ${ }^{1}$ A. A. \\ 1. Department of Biological Applications, Radioisotopes Applications Division, Nuclear Research Center, \\ Atomic Energy Authority, Inshas, Cairo, Egypt, P.O.13759 \\ 2. Department of Animal Production, Faculty of Agriculture, Benha University, Cairo, Egypt, P.O.13736.
}

\begin{abstract}
.
This experiment was conducted to study the effect of the treating Baladi female goats with chromium and selenium-E during estrous cycle, pregnancy and postpartum periods to alleviate thermoregulatory responses of animals under hot conditions in Egypt to improve their performance throughout these stages. It has been used in this research 72 mature Baladi does (36 animal / season) with an average age of 2-3 years and an average body weight of $25 \mathrm{Kg}$, the experiment lasted for two seasons (mild and hot). Animals were divided randomly into three similar groups, the $1^{\text {st }}$ group was kept without any treatments (control), the 2 nd group was supplemented by chromium (chromium chloride, $\mathrm{Cr}$ ). The $3^{\text {rd }}$ group was injected intramuscularly twice a week with $2 \mathrm{ml}$ viteselen ${ }^{\circledR}$, contained $0.5 \mathrm{mg}$ selenium and $10.7 \mathrm{IU}$ vitamin $\mathrm{E}$ (Se-E). Animals were kept in semi-open pens during the experimental period and allowed to graze for five hours daily at least. Thermoregulatory responses of the animal were estimated in terms of rectal temperature (RT), skin temperature (ST) and respiratory rate (RR). Results showed significant decrease in RT during the estrous cycle due to $\mathrm{Cr}$ and $\mathrm{Se}-\mathrm{E}$ treatments. Also, Selenium-E injection showed lower ST during most of the different stages of estrous cycle. Under hot season, each of chromium and selenium-E reduced ST during estrous cycle while this effect was only due to Se-E for RR without chromium .Both $\mathrm{Cr}$ and Se-E treatments decreased RT and ST throughout different stages of pregnancy, except at late pregnancy of Se-E group. Under hot season conditions, does injected with Se-E were the lowest in RR during the mid and late pregnancy compared with other groups. While Cr group did not reveal significant effect on RR. During postpartum period $\mathrm{Cr}$ and Se-E supplementation under hot condition showed significant decrease in RT and ST. Both treatments decreased $(\mathrm{P}<0.05)$ RR during the postpartum period, only Se-E exhibited this decline under hot season.
\end{abstract}

Key words: Heat stress, rectal temperature, skin temperature, respiration rate, Chromium, Selenium-E, female goats

\section{Introduction}

Heat stress has a reducing effect on both the productivity and reproductive efficiency of farm animals (Jordan, 2003). The deleterious effects of heat stress are the result of either the hyperthermia associated with heat stress or the physiological adjustments made by the heat-stressed animal to regulate body temperature (Hansen, 2009).

Rectal temperature (RT), skin temperature (ST) and respiration rate (RR) are parameters which illustrate the mechanism of physiological adaptation (Marai et al., 2007; Otoikhian et al., 2009; Phulia et al., 2010; Sharma et al., 2013). Rectal temperature of goats was found to be elevated with high environmental temperature in several studies (Devendra, 1987; Marai et al., 2007). Even a rise of less than $1^{\circ} \mathrm{C}$ in rectal temperature was enough to reduce performance in most livestock species which makes the body a sensitive indicator of physiological response to heat stress (Shebaita and El-Banna, 1982).

During exposure to heat, ST was increased due to vasodilation which was beneficial for increasing heat loss from the skin (Slee, 1966). Also, Alam et al., (2011) stated that the respiration rate increased significantly $(\mathrm{P}<0.01)$ with increasing the period of exposure to heat stress (from 4 to $8 \mathrm{~h}$. per day) compared to the control group ( $0 \mathrm{~h}$. heat exposure).

The primary role of chromium in metabolism is in enhancing the glucose uptake by the cells (Davis and Vincent, 1997). Chromium also activates certain enzymes and stabilizes proteins and nucleic acids (Anderson, 1994). Chromium supplementation reduces the negative effects of environmental stress (Mowat, 1994; Lien et al., 1999; Sahin et al., 2001).

Heat stress is associated with changes in antioxidant status by promoting oxidative stress and reducing the blood concentrations of antioxidant micronutrients (zinc, selenium, and vitamin E) in ruminants (Bernabucci et al., 2002; Burke et al., 2007). Selenium is an essential trace element vital for the normal growth and health of animals. Selenium (Se) has a biological function related to vitamin $\mathrm{E}$ in that $\mathrm{Se}$ is an essential component of glutathion peroxidase, an enzyme involved in detoxification of hydrogen peroxide and lipid hydroperoxides. Moreover, Se is a component of selenoproteins and is involved in immune and neuropsychological function in the nutrition of animals (Meschy, 2000). Alhidary et al., (2012) found that mean RT of sheep injected with $5 \mathrm{mg}$ of Se was $0.3^{\circ} \mathrm{C}$ less than that of the control 
sheep $\left(39.5^{\circ} \mathrm{C}\right.$ vs. $\left.39.8^{\circ} \mathrm{C}\right)$. However, there were no differences in RR between groups.

The objective of this study was focused on the importance of treating Baladi female goats with chromium and selenium-E to alleviate the adverse effect of heat stress on thermoregulatory responses (rectal temperature, skin temperature and respiration rate) during estrous cycle, pregnancy and postpartum period.

\section{Materials and Methods}

\section{Animals and feeding:}

This experiment was carried out in the Experimental Farms Project (Goats Farm), Nuclear Research Center, Atomic Energy Authority, Inshas. The experimental animals were healthy and clinically free of external and internal parasites and were fed basal ration of concentrate feed mixture (CFM) according to the allowances of NRC ( 2007) of goats. The CFM composed of $37.4 \%$ wheat bran, $27 \%$ yellow corn, $12.5 \%$ soybean meal, $10.0 \%$ undecorticated cottonseed cake, $5 \%$ rice bran, $4 \%$ sugarcane molasses, $3 \%$ limestone, $1 \%$ sodium chloride and 0.1 vitamin and minerals premix. Feed mixture was offered once daily at $10 \mathrm{am}$,based on $3.5 \%$ of body weight. Barseem hay was offered ad libitum. Fresh drinking water was available at all time.

\section{Animal housing:}

All experimental animals were kept in semi-open pens throughout the experimental period. These pens were provided with enough shade and ventilation in summer and protection from rain in winter. The does were allowed to graze five hours daily at least.

\section{Experimental design:}

Seventy-two mature female goats (36 animals/ season) aged 2-3 years old with average body weigh $25 \pm 1.5 \mathrm{~kg}$ were randomly divided into three similar groups. Animals in the $1^{\text {st }}$ group were kept without any treatments (control), the $2^{\text {nd }}$ group was supplemented by chromium (chromium chloride trivalent), $0.8 \mathrm{mg} / \mathrm{head} /$ day as capsules (Williams et al., 1994) and the $3^{\text {rd }}$ group was injected intramuscularly with $2 \mathrm{ml}$ viteselen ${ }^{\circledR}$, contained 0.5 mg selenium and 10.7 IU vitamin E/head/day.

\section{Ambient temperature, relative humidity and temperature humidity index:}

The ambient temperature and relative humidity were recorded daily from meteorological station of Atomic Energy Authority during the whole experimental period. The temperature humidity index (THI) was calculated during mild and hot seasons according to Marai et al., (2000) as:

$\mathrm{THI}=\mathrm{db}{ }^{\circ} \mathrm{C}-\left[(0.31-0.31 \mathrm{RH}) \times\left(\mathrm{db}{ }^{\circ} \mathrm{C}-14.4\right)\right]$

Where, THI $=$ temperature humidity index, $\mathrm{db}{ }^{\circ} \mathrm{C}=$ dry bulb temperature in Celsius and $\mathrm{RH}=$ relative humidity $\div 100$.

A value for THI $<22.2$ was considered remarkably an absence of heat stress, while the values from 22.2 to 23.3 referred to moderate (mild) heat stress, 23.3 to $<25.6$ referred to severe heat stress and >25.6 referred to very severe heat stress.

\section{Rectal and skin temperature:}

Rectal temperature $\left(\mathrm{RT},{ }^{\circ} \mathrm{C}\right)$ was measured using digital clinical thermometer. Skin temperature (ST, ${ }^{\circ} \mathrm{C}$ ) was measured using $\mathrm{K}$ type sensor digital thermometer, model: 301 with measuring range: $50^{\circ} \mathrm{C}$ to $1300^{\circ} \mathrm{C}$.

\section{Respiratory rate:}

Respiration rate (RR) was expressed as the number of respirations per minute (breaths/min.) and was measured by counting the flank movements in one minute. Complete inward and outward movement of the flank was counted as one respiration.

\section{Statistical analysis}

Data were expressed as mean \pm SE. Data were analyzed statistically by GLM procedure of the SAS program (SAS, 1998). Duncan's Multiple Range test was used to detect the differences among means of the experimental groups (Duncan, 1955).

$\mathrm{Y}_{\mathrm{ijk}}=\mu+\mathrm{S}_{\mathrm{i}}+\mathrm{T}_{\mathrm{j}}+(\mathrm{ST})_{\mathrm{ij}}+\mathrm{e}_{\mathrm{ijk}}$

Where, $\mathrm{Y}_{\mathrm{ijk}}=$ the dependent variables estimated, $\mu=$ Overall mean, $S_{i}=$ the effect of $i^{\text {th }}$ season $(1=$ mild and $2=$ hot $), T_{j}=$ the effect of $j^{\text {th }}$ treatment $(1=$ control, $2=$ chromium and $3=$ selenium-E), $\mathrm{ST}_{\mathrm{ij}}=$ the effect of interaction between season and treatment and $\mathrm{e}_{\mathrm{ijk}}=$ random error.

\section{Results}

1. Rectal temperature, skin temperature and respiration rate during estrous cycle:

It is obviously clear that RT, ST and RR were significantly $(\mathrm{P}<0.05)$ affected by season and treatments used in this study throughout different stages of estrous cycle as shown in Table 1. Treating does with chromium $(\mathrm{Cr})$ or selenium-vitamin $\mathrm{E}$ (SeE) significantly $(\mathrm{P}<0.05)$ reduced rectal temperature values compared with control group during estrous cycle. The lowest RT was $38.82 \pm 0.06$ and $38.99 \pm$ $0.07^{\circ} \mathrm{C}$ recorded by $\mathrm{Se}-\mathrm{E}$ does at diestrus and estrus period with difference about -0.37 and $-0.32{ }^{\circ} \mathrm{C}$ less than control, respectively. Whereas, the lowest RT recorded due to $\mathrm{Cr}$ treatment was $39.03 \pm 0.09^{\circ} \mathrm{C}$ and $39.04 \pm 0.04{ }^{\circ} \mathrm{C}$ at diestrus and metestrus phases, but only metestrus phase was significantly $(\mathrm{P}<0.05)$ less by about $-0.60{ }^{0} \mathrm{C}$ than control. It was found that, goats showed low ST in mild season than hot. In addition, does treated by Se-E had lower ST (37.69, 38.15 and $37.33{ }^{\circ} \mathrm{C}$ ) at diestrus, proestrus and estrus phases than either those treated by $\mathrm{Cr}$ or control group respectively, Whereas, $\mathrm{Cr}$ group showed only low significant ST $38.0 \pm 0.17^{\circ} \mathrm{C}$ at metestrus, otherwise, it did not show any significance comparing with control group (Table 1). 
Table 1. Means $( \pm \mathrm{SE})$ for factors affecting rectal temperature, skin temperature $\left({ }^{\circ} \mathrm{C}\right)$ and respiration rate (breathes/min) of Does during postpartum period.

\begin{tabular}{|c|c|c|c|c|c|c|c|c|c|c|c|c|}
\hline \multirow{3}{*}{ Items } & \multicolumn{12}{|c|}{ Estrous cycle phases } \\
\hline & \multicolumn{3}{|c|}{ Diestrus } & \multicolumn{3}{|c|}{ Proestrus } & \multicolumn{3}{|c|}{ Estrus } & \multicolumn{3}{|c|}{ Metestrus } \\
\hline & RT & ST & $\mathbf{R R}$ & RT & ST & $\mathbf{R R}$ & RT & ST & $\mathbf{R R}$ & RT & ST & $\mathbf{R R}$ \\
\hline \multicolumn{13}{|l|}{ Season $(\mathrm{S})$} \\
\hline Mild & $39.03 \pm 0.03$ & $37.82 \pm 0.07$ & $26 \pm 0.42$ & $39.42 \pm 0.06$ & $37.76 \pm 0.06$ & $27 \pm 0.77$ & $39.08 \pm 0.06$ & $37.46 \pm 0.07$ & $25 \pm 0.8$ & $39.17 \pm 0.06$ & $37.98 \pm 0.12$ & $24 \pm 0.5$ \\
\hline Hot & $38.99 \pm 0.08$ & $38.20 \pm 0.12$ & $25 \pm 0.22$ & $39.87 \pm 0.09$ & $38.75 \pm 0.11$ & $26 \pm 0.40$ & $39.24 \pm 0.07$ & $38.22 \pm 0.12$ & $24 \pm 0.4$ & $39.49 \pm 0.05$ & $38.81 \pm 0.09$ & $26 \pm 0.3$ \\
\hline P-value & 0.697 & 0.002 & 0.042 & 0.0001 & 0.0001 & 0.113 & 0.044 & 0.0001 & 0.193 & 0.0001 & 0.0001 & 0.0001 \\
\hline \multicolumn{13}{|l|}{ Treats (T) } \\
\hline Control & $39.19^{\mathrm{A}} \pm 0.08$ & $38.21^{\mathrm{A}} \pm 0.14$ & $26^{\mathrm{A}} \pm 0.52$ & $39.56^{\mathrm{B}} \pm 0.09$ & $38.28 \pm 0.13$ & $27^{\mathrm{A}} \pm 0.67$ & $39.31^{\mathrm{A}} \pm 0.10$ & $38.07^{\mathrm{A}} \pm 0.17$ & $25 \pm 0.3$ & $39.64^{\mathrm{A}} \pm 0.07$ & $38.68^{\mathrm{A}} \pm 0.11$ & $27^{\mathrm{A}} \pm 0.21$ \\
\hline $\mathrm{Cr}$ & $39.03^{\mathrm{A}} \pm 0.09$ & $38.13^{\mathrm{A}} \pm 0.13$ & $26^{\mathrm{A}} \pm 0.38$ & $39.60^{\mathrm{B}} \pm 0.05$ & $38.34 \pm 0.11$ & $28^{\mathrm{A}} \pm 0.77$ & $39.19^{\mathrm{A}} \pm 0.04$ & $38.12^{\mathrm{A}} \pm 0.07$ & $25 \pm 1.1$ & $39.04^{\mathrm{C}} \pm 0.04$ & $38.00^{\mathrm{B}} \pm 0.17$ & $24^{\mathrm{C}} \pm 0.27$ \\
\hline Se-E & $38.82^{\mathrm{B}} \pm 0.06$ & $37.69^{\mathrm{B}} \pm 0.06$ & $25^{\mathrm{B}} \pm 0.28$ & $39.79^{\mathrm{A}} \pm 0.15$ & $38.15 \pm 0.21$ & $24^{\mathrm{B}} \pm 0.55$ & $38.99^{\mathrm{B}} \pm 0.07$ & $37.33^{\mathrm{B}} \pm 0.10$ & $24 \pm 0.8$ & $39.31^{\mathrm{B}} \pm 0.08$ & $38.51^{\mathrm{A}} \pm 0.15$ & $25^{\mathrm{B}} \pm 0.55$ \\
\hline $\begin{array}{l}\text { P- value } \\
S * T\end{array}$ & 0.003 & 0.001 & 0.01 & 0.044 & 0.433 & 0.0001 & 0.004 & 0.0001 & 0.417 & 0.0001 & 0.0001 & 0.0001 \\
\hline \multicolumn{13}{|l|}{ Mild } \\
\hline Control & $39.13 \pm 0.07$ & $37.70^{\mathrm{cd}} \pm 0.02$ & $26^{\mathrm{ab}} \pm 0.96$ & $39.68^{b} \pm 0.07$ & $38.00^{\mathrm{c}} \pm 0.04$ & $29^{\mathrm{a}} \pm 0.77$ & $39.08^{\mathrm{cd}} \pm 0.09$ & $37.43^{c} \pm 0.08$ & $25^{\mathrm{a}} \pm 0.6$ & $39.48^{\mathrm{b}} \pm 0.10$ & $38.63^{\mathrm{b}} \pm 0.02$ & $27^{\mathrm{a}} \pm 0.36$ \\
\hline $\mathrm{Cr}$ & $39.03 \pm 0.13$ & $38.15^{\mathrm{b}} \pm 0.16$ & $27^{\mathrm{a}} \pm 0.58$ & $39.53^{\mathrm{b}} \pm 0.08$ & $38.00^{\mathrm{c}} \pm 0.11$ & $29^{\mathrm{a}} \pm 1.50$ & $39.00^{\mathrm{cd}} \pm 0.04$ & $37.78^{\mathrm{b}} \pm 0.05$ & $24^{\mathrm{a}} \pm 2.1$ & $39.03^{c} \pm 0.08$ & $37.45^{\mathrm{d}} \pm 0.25$ & $23^{\mathrm{b}} \pm 0.39$ \\
\hline Se-E & $38.93 \pm 0.05$ & $37.60^{\mathrm{d}} \pm 0.06$ & $25^{\mathrm{bc}} \pm 0.48$ & $39.08^{c} \pm 0.06$ & $37.28^{\mathrm{d}} \pm 0.07$ & $23^{\mathrm{d}} \pm 0.65$ & $39.17^{b c} \pm 0.13$ & $37.18^{c} \pm 0.11$ & $27^{\mathrm{a}} \pm 1.0$ & $39.00^{c} \pm 0.07$ & $37.88^{\mathrm{c}} \pm 0.09$ & $24^{\mathrm{b}} \pm 0.86$ \\
\hline \multicolumn{13}{|l|}{ Hot } \\
\hline Control & $39.25 \pm 0.14$ & $38.73^{\mathrm{a}} \pm 0.18$ & $26^{\mathrm{ab}} \pm 0.43$ & $39.45^{\mathrm{b}} \pm 0.16$ & $38.55^{\mathrm{b}} \pm 0.23$ & $24^{\mathrm{cd}} \pm 0.43$ & $39.55^{\mathrm{a}} \pm 0.15$ & $38.72^{\mathrm{a}} \pm 0.17$ & $25^{\mathrm{a}} \pm 0.2$ & $39.80^{\mathrm{a}} \pm 0.04$ & $38.73^{\mathrm{ab}} \pm 0.22$ & $27^{\mathrm{a}} \pm 0.22$ \\
\hline $\mathrm{Cr}$ & $39.03 \pm 0.12$ & $38.10^{\mathrm{bc}} \pm 0.22$ & $25^{\mathrm{bc}} \pm 0.21$ & $39.68^{\mathrm{b}} \pm 0.06$ & $38.68^{\mathrm{ab}} \pm 0.15$ & $28^{\mathrm{ab}} \pm 0.45$ & $39.38^{\mathrm{ab}} \pm 0.03$ & $38.46^{a} \pm 0.03$ & $26^{a} \pm 0.3$ & $39.05^{\mathrm{c}} \pm 0.05$ & $38.55^{\mathrm{b}} \pm 0.05$ & $24^{\mathrm{b}} \pm 0.25$ \\
\hline Se-E & $38.70 \pm 0.09$ & $37.78^{\mathrm{bcd}} \pm 0.11$ & $24^{\mathrm{c}} \pm 0.21$ & $40.50^{\mathrm{a}} \pm 009$ & $39.03^{\mathrm{a}} \pm 0.19$ & $26^{b c} \pm 0.68$ & $38.80^{\mathrm{d}} \pm 0.02$ & $37.48^{\mathrm{bc}} \pm 0.13$ & $21^{b} \pm 0.3$ & $39.63^{\mathrm{ab}} \pm 0.03$ & $39.15^{\mathrm{a}} \pm 0.10$ & $26^{\mathrm{a}} \pm 0.36$ \\
\hline P-value & 0.224 & 0.001 & 0.046 & 0.0001 & 0.0001 & 0.0001 & 0.0001 & 0.0001 & 0.0001 & 0.0001 & 0.0001 & 0.016 \\
\hline
\end{tabular}

Means with different superscripts (A, B and $\mathrm{C}$ or $\mathrm{a}, \mathrm{b}, \mathrm{c}, \ldots)$ in the same column are significantly different at $(\mathrm{P}<0.05)$.

$\mathrm{Cr}=$ chromium, $\mathrm{Se}-\mathrm{E}=$ Selenium + Vitamin-E. 
Under hot conditions the animals received $\mathrm{Cr}$ showed significantly $(\mathrm{P}<0.05)$ lower RT $(39.05 \pm 0.05$ $\left.{ }^{0} \mathrm{C}\right)$ at metestrus than control $\left(39.80 \pm 0.04^{\circ} \mathrm{C}\right)$. The significant decrease in RT due Se-E was $38.8 \pm$ $0.02^{\circ} \mathrm{C}$ at estrus period versus $39.55 \pm 0.15^{\circ} \mathrm{C}$ for control. The marked reduction RT $\left(38.7^{\circ} \mathrm{C}\right)$ was due Se-E treatment at diestrus phase in hot season. However, treating female goats with $\mathrm{Cr}$ under hot condition showed insignificant decrease in ST during diestrus, estrus and metestrus phase compared with control. Se-E injection lowered ST significantly at diestrus and metestrus phase with mean values of 37.78 and $37.48^{\circ} \mathrm{C}$ vs. 38.73 and $38.72^{\circ} \mathrm{C}$ for control, respectively.

It is worthy to mention that, Se-E treated does almost had the lowest RR (24 breathes/min) during proestrus and estrus phases compared with control and $\mathrm{Cr}$ group. $\mathrm{Cr}$ group showed significantly lower RR ( $24 \pm 0.27$ breathes/min) at metestrus compering with other groups. Under hot conditions Se-E group showed significantly marked decrease $(21 \pm 0.3$ breathes/min) in RR at estrus period comparing with $26 \pm 0.43$ breathes/min for control. However, does supplied by $\mathrm{Cr}$ showed a fluctuated RR results during estrous, showing the highest RR (28 \pm 0.45 breathes/min) at proestrus and lowest RR (24 \pm 0.25 breathes/min) at metestrus compared with control (Table 1).

\section{Rectal temperature, skin temperature and respiration rate during pregnancy:}

Inspection the effect of treatments on RT, it is noticeable that $\mathrm{Cr}$ treatment decreased RT during early, mid and late pregnancy compared with control. Does injected with Se-E showed the same trend of RT. Cr group at late pregnancy recorded the lowest $\left(38.03 \pm 0.3{ }^{\circ} \mathrm{C}\right) \mathrm{RT}$, however the higher value was about $39.14 \pm 0.08{ }^{\circ} \mathrm{C}$ for control at early pregnancy (Table 2). Cr or Se-E treated does had significantly $(\mathrm{P}<0.05$ or $\mathrm{p}<0.0001)$ lower $\mathrm{ST}$ values than control group. Chromium group had the upper hand in decreasing ST during mid $\left(37.67 \pm 0.19^{\circ} \mathrm{C}\right)$ and late $\left(37.55 \pm 0.21^{\circ} \mathrm{C}\right)$ pregnancy more than Se-E treatment. Cr showed significant $(\mathrm{P}<0.05$ or $\mathrm{p}<0.0001)$ increase in $\mathrm{RR}$ especially during mid and late pregnancy compared with control group. On the other hand, injection with Se-E during pregnancy revealed fluctuated trend of $R R$, showing an increase $(\mathrm{P}<0.05)$ at early pregnancy and a decrease $(\mathrm{P}<0.05)$ at late pregnancy comparing with control (Table 2 ).

Under mild and hot conditions, treated groups almost had RT values lower than control group during early pregnancy (EP), mid-pregnancy (MP) and late pregnancy (LP). The lowest RT was about $36.63 \pm 0.18^{\circ} \mathrm{C}$ recorded by $\mathrm{Cr}$ does, followed by $37.23 \pm 0.09^{\circ} \mathrm{C}$ for Se-E does during late pregnancy under mild condition. However, the lowest RT in the hot season was about $38.5 \pm 0.05^{\circ} \mathrm{C}$ for $\mathrm{Cr}$ does and $38.65 \pm .03^{\circ} \mathrm{C}$ for $\mathrm{Se}-\mathrm{E}$ group at EP. Cr treatment had markedly lower ST $\left(36.76 \pm 0.05^{\circ} \mathrm{C}\right.$ and $\left.36.63 \pm 0.18^{\circ} \mathrm{C}\right)$ during mid and late pregnancy, respectively, comparing with other groups under mild conditions. Under hot season conditions, goats' ST response to applied treatments found to be higher magnitude in Se-E than Cr during early, mid and late pregnancy with the lowest ST $37.75 \pm 0.09^{\circ} \mathrm{C}$ at early pregnancy (Table 2).

Respiration rate of does treated by $\mathrm{Cr}$ or $\mathrm{Se}-\mathrm{E}$ was higher than control during early and midpregnancy of mild season. At late pregnancy $\mathrm{Cr}$ does had the highest ( $27 \pm 0.57$ breathes/min) RR among other groups. However, under hot conditions Se-E does recorded the lowest RR $(25 \pm 0.3$ and $26 \pm 0.37)$ breathes/min at mid and late pregnancy comparing with $27 \pm 0.5$ and $31 \pm 0.21$ breathes/min for the other groups, (Table 2).

\section{Rectal temperature, skin temperature and respiration rate during postpartum period (PP) :}

Applying $\mathrm{Cr}$ or Se-E led to significant decrease $(\mathrm{P}<0.05)$ in $\mathrm{RT}, \mathrm{ST}$ and $\mathrm{RR}$ during postpartum compared with control. Goats received $\mathrm{Cr}$ showed the lowest RT during $30^{\text {th }}$ and $45^{\text {th }}$ days PP with mean values of about $39.05 \pm 0.06$ and $38.86 \pm 0.12{ }^{\circ} \mathrm{C}$, respectively; however the significant decrease due to Se-E was $39.15 \pm 0.09{ }^{\circ} \mathrm{C}$ on day-30 PP. Furthermore, Cr decreased $(\mathrm{P}<0.05) \mathrm{ST}$ on the $15^{\text {th }}$ and $45^{\text {th }}$ days postpartum with mean values of $37.53 \pm 0.10^{\circ} \mathrm{C}$ and $37.87 \pm 0.08{ }^{\circ} \mathrm{C}$, respectively. While, Se-E treatment lowered ST markedly $\left(37.89 \pm 0.1{ }^{\circ} \mathrm{C}, \mathrm{P}<0.05\right)$ on $30^{\text {th }}$ day PP comparing with other groups. The higher RR was $27 \pm 0.91$ breathes/min on the $15^{\text {th }}$ day PP for $\mathrm{Cr}$ group, while the lowest RR recorded was 24 breathes/min for Se-E at $15^{\text {th }}$ and $30^{\text {th }}$ day PP (Table 3).

In hot season, the significant decrease in RT was due to Se-E injection on $30^{\text {th }}$ and $45^{\text {th }}$ days PP with mean values of $38.72 \pm 0.05^{\circ} \mathrm{C}$ and $39.2 \pm 0.02{ }^{\circ} \mathrm{C}$, respectively, in addition to significant lower $\mathrm{RT}$ $39.37 \pm 0.13^{\circ} \mathrm{C}$ on day-45 PP due to $\mathrm{Cr}$ treatment versus $39.6 \pm 0.03^{\circ} \mathrm{C}$ for control. $\mathrm{Cr}$ decreased $(\mathrm{P}<0.05) \mathrm{ST}$ on the $15^{\text {th }}$ and $45^{\text {th }}$ day PP during hot and mild season with vale of about $37.5^{\circ} \mathrm{C}$. The same effect was obtained during mild and hot seasons on $45^{\text {th }}$ day PP compared with control with values of $37.6 \pm 0.1{ }^{0} \mathrm{C}$ vs. $38.18 \pm 0.42{ }^{\circ} \mathrm{C}$ and $38.15 \pm 0.08{ }^{\circ} \mathrm{C}$ vs. $38.6 \pm 0.45^{\circ} \mathrm{C}$, respectively. On the other side, SeE group gave significant lower $\left(37.46 \pm 0.06{ }^{\circ} \mathrm{C}\right) \mathrm{ST}$ than other groups on the $30^{\text {th }}$ day PP during hot season.

Does treated with $\mathrm{Cr}$ or Se-E during PP period showed RR lower $(\mathrm{P}<0.05)$ than control under mild season, chromium group recorded low RR (26 breathes/min) on the days 15 and 45 postpartum. However, under hot season, does injected with Se-E had the lowest RR (20 breathes/min) on $15^{\text {th }}$ and $30^{\text {th }}$ day postpartum and $24 \pm 0.42$ breathes $/ \mathrm{min}$ on the $45^{\text {th }}$ day PP followed by $\mathrm{Cr}$ group with RR $21 \pm 0.57$ on day 30 PP compared with control does (Table 3 ). 


\section{Discussion}

The decrease in rectal temperature due to $\mathrm{Cr}$ supplementation in the current study agree with the findings of Kobeisy et al., (2004) who found that chromium supplementation tended to decrease rectal temperature in sheep. Furthermore, Moonsie-Shgeer and Mowat (1993) found that supplemental $\mathrm{Cr}$ (from highy-Cr yeast) tended to reduce rectal temperatures in stressed feeder calves. In the same trend, Liu et al., (2015) on heat stressed growing pigs stated that, compared with control diet, $\mathrm{Cr}$ pigs had lower RT (40.2 vs. 39.9, $\mathrm{P}<0.05)$ under heat stress (HS) conditions, indicating an amelioration in the level of $\mathrm{HS}$ experienced in $\mathrm{Cr}$ pigs.

Whereas, these results disagreed with the finding of Yari et al. (2010) who concluded that supplementation of calves pre and post-weaning in summer season had no effect on rectal temperature between all experimental groups. An-Qiang et al. (2009) studied the effect of $\mathrm{Cr}$ picolinate addition to heat stressed lactating Holstein cows (15-24 days post-partum), and reported no significant effect on rectal temperatures, respiration rates due to $\mathrm{Cr}$ treatment. In growing lambs, supplementation with chromium picolinate at doses of 50, 75 and $100 \mathrm{mg}$ per $\mathrm{kg}$ diets under the summer Egyptian conditions did not show any effect on rectal temperature (Abd El-Monem and Abd El-Hamid, 2008).

With regard to the decrease in rectal temperature observed in goats injected with Se-E, Alhidary et al. (2012) found that, sheep injected with $1 \mathrm{ml}$ of sodium selenate $(5 \mathrm{mg} \mathrm{Se})$ was approximately $0.3^{\circ} \mathrm{C}$ less than that of the control sheep $\left(39.7^{\circ} \mathrm{C}\right.$ vs. $40.0^{\circ} \mathrm{C}$ ).

Skin temperature results for untreated group agreed with Fahmy (1994), Marai et al. (1997) and khalifa et al. (2000) with goats. The authors stated an increase in ST as a result of exposure to heat stress conditions. Skin temperature is a physiological parameter that can be used for heat stress assessment as the heat exchange between the body and environment is achieved through the skin. The adjustment of skin blood flow to regulate transfer of heat from body core to the skin results in a shift in skin temperature in response to elevated temperatures (Habeeb et al., 1992). The current significant decrease in ST due to Se-E supplementation at estrous cycle ( diestrus and estrus phase), pregnancy and postpartum period under hot season conditions is in agreement with Zeidan et al. (2001) and Al-Zafry and Medan (2012) with New Zealand white rabbits. The authors found that supplementation with Se-E significantly reduced skin temperature than control group of heat stressed rabbits, indicating that injection of vitamin $\mathrm{E}$ and selenium complex ameliorates the heat stress effect. Whereas, Chauhan et al. (2015) with sheep exposed to heat stress condition reported an increase in ST by increasing ambient temperature and found nonsignificant effect due to Se-E dietary supplementation on
ST as compared to control group that disagree with the current study results of Se-E.

On the other side, Abdulaziz (2006) studied the effect of heat stress and supplemental chromium on thermo-respiratory responses in non-pregnant Saidi ewes exposed to direct solar radiation for two contentious hours and found that $\mathrm{Cr}$ supplementation had no significant effect on skin temperature. The present results are in agreement with those of Abdulaziz (2006) in respect of $\mathrm{Cr}$ results of estrus and postpartum under hot season conditions, but disagreed with pregnancy period results which revealed significant decrease in ST due to chromium supplementation. Inspection of the current hot season results of $\mathrm{Cr}$ treatment during estrous, pregnancy and postpartum periods; it generally did not have significant effect on respiration rate compared with control. The current results are in agreement with those of Lacetera et al., (2002) who concluded that administration of $\mathrm{Cr}$ to heat-stressed periparturient cows did not significantly affect respiration rate. However, under mild conditions the present results are in contrary with the findings of the same author, which revealed significant decrease in $\mathrm{RR}$ due to $\mathrm{Cr}$ supplementation (Table 2). In addition, An-Qiang et al., (2009) studied the effect of Cr Picolinate addition to heat stressed lactating Holstein cows (15 - 45 days postpartum), and found no significant effect on respiration rates due to $\mathrm{Cr}$ supplementation. Results of Se-E revealed significant decrease in respiration rate under hot season conditions throughout estrous, pregnancy and postpartum periods. These results agree with finding of Chauhan et al., (2015), who studied the ameliorative effect of selenium and vitamin-E dietary supplementation in heat stressed sheep and found that sheep given combined diet of Se and vitamin $\mathrm{E}$ had a lower respiration rate under HS compared with those fed the low Se and vitamin $\mathrm{E}$ diet or control. Whereas, the current results disagree with those of El-Shahat and Abdel Monem (2011) and Alhidary et al. (2012) in heat stressed sheep. The authors stated that treating sheep with Se alone or Se and /or vitamin E did not have significant effect on respiration rate.

In conclusion, this study revealed that chromium and selenium-E supplementation could be used to alleviate heat stress effects since it showed decrease in thermoregulatory responses during some stages of estrous, pregnancy and postpartum periods of Baladi does specially under hot season. 
Table 2. Means $\left( \pm\right.$ SE) for factors affecting rectal temperature, skin temperature $\left({ }^{\circ} \mathrm{C}\right)$ and respiration rate $($ breathes/min) of does during pregnancy period.

\begin{tabular}{|c|c|c|c|c|c|c|c|c|c|}
\hline \multirow{3}{*}{ Items } & \multicolumn{9}{|c|}{ Pregnancy Period } \\
\hline & \multicolumn{3}{|c|}{ Early pregnancy } & \multicolumn{3}{|c|}{ Mid-pregnancy } & \multicolumn{3}{|c|}{ Late pregnancy } \\
\hline & RT & ST & $\mathbf{R R}$ & RT & ST & $\mathbf{R R}$ & RT & ST & $\mathbf{R R}$ \\
\hline \multicolumn{10}{|l|}{ Season $(S)$} \\
\hline Mild & $39.09 \pm 0.05$ & $37.53 \pm 0.04$ & $26 \pm 0.3$ & $38.37 \pm 0.07$ & $37.11 \pm 0.09$ & $25 \pm 0.3$ & $37.04 \pm 0.81$ & $37.04 \pm 0.81$ & $25 \pm 0.44$ \\
\hline Hot & $38.68 \pm 0.05$ & $38.16 \pm 0.08$ & $22 \pm 0.4$ & $38.93 \pm 0.06$ & $38.85 \pm 0.10$ & $26 \pm 0.3$ & $39.39 \pm 0.02$ & $38.29 \pm 0.06$ & $29 \pm 0.42$ \\
\hline P-value & 0.0001 & 0.0001 & 0.0001 & 0.0001 & 0.0001 & 0.005 & 0.0001 & 0.0001 & 0.0001 \\
\hline \multicolumn{10}{|l|}{ Treatments (T) } \\
\hline Control & $39.14^{\mathrm{A}} \pm 0.08$ & $38.10^{\mathrm{A}} \pm 0.14$ & $23^{\mathrm{B}} \pm 0.5$ & $38.93^{\mathrm{A}} \pm 0.08$ & $38.59^{\mathrm{A}} \pm 0.22$ & $25^{\mathrm{B}} \pm 0.5$ & $38.28^{\mathrm{A}} \pm 0.21$ & $37.81^{\mathrm{A}} \pm 0.12$ & $28^{\mathrm{B}} \pm 0.80$ \\
\hline $\mathrm{Cr}$ & $38.81^{\mathrm{B}} \pm 0.07$ & $37.84^{\mathrm{B}} \pm 0.04$ & $24^{\mathrm{A}} \pm 0.6$ & $38.48^{\mathrm{B}} \pm 0.09$ & $37.67^{\mathrm{B}} \pm 0.19$ & $27^{\mathrm{A}} \pm 0.3$ & $38.03^{\mathrm{B}} \pm 0.30$ & $37.55^{\mathrm{B}} \pm 0.21$ & $29^{\mathrm{A}} \pm 0.49$ \\
\hline Se-E & $38.71^{\mathrm{B}} \pm 0.03$ & $37.59^{\mathrm{C}} \pm 0.06$ & $24^{\mathrm{A}} \pm 0.7$ & $38.53^{\mathrm{B}} \pm 0.08$ & $37.69^{\mathrm{B}} \pm 0.17$ & $25^{\mathrm{B}} \pm 0.2$ & $38.34^{\mathrm{A}} \pm 0.23$ & $37.63^{\mathrm{AB}} \pm 0.11$ & $24^{\mathrm{C}} \pm 0.41$ \\
\hline P-value & 0.0001 & 0.0001 & 0.034 & 0.0001 & 0.0001 & 0.0001 & 0.001 & 0.033 & 0.0001 \\
\hline \multicolumn{10}{|l|}{$\mathbf{S} * \mathbf{T}$} \\
\hline \multicolumn{10}{|l|}{ Mild } \\
\hline Control & $39.39^{\mathrm{a}} \pm 0.05$ & $37.45^{\mathrm{d}} \pm 0.05$ & $24 \pm 0.2$ & $38.68 \pm 0.10$ & $37.57^{c} \pm 0.13$ & $23^{c} \pm 0.7$ & $37.25^{\mathrm{b}} \pm 0.01$ & $37.25^{\mathrm{c}} \pm 0.01$ & $24^{\mathrm{c}} \pm 0.67$ \\
\hline $\mathrm{Cr}$ & $39.13^{\mathrm{b}} \pm 0.07$ & $37.70^{c} \pm 0.5$ & $26 \pm 0.3$ & $38.08 \pm 0.08$ & $36.76^{\mathrm{d}} \pm 0.05$ & $26^{\mathrm{ab}} \pm 0.2$ & $36.63^{\mathrm{c}} \pm 0.18$ & $36.63^{\mathrm{d}} \pm 0.18$ & $27^{\mathrm{b}} \pm 0.57$ \\
\hline Se-E & $38.76^{\mathrm{cd}} \pm 0.04$ & $37.43^{\mathrm{d}} \pm 0.06$ & $27 \pm 0.6$ & $38.35 \pm 0.09$ & $37.00^{\mathrm{d}} \pm 0.16$ & $25^{\mathrm{b}} \pm 0.3$ & $37.23^{\mathrm{b}} \pm 0.09$ & $37.23^{c} \pm 0.09$ & $23^{c} \pm 0.32$ \\
\hline \multicolumn{10}{|l|}{ Hot } \\
\hline Control & $38.90^{\mathrm{c}} \pm 0.10$ & $38.75^{\mathrm{a}} \pm 0.06$ & $22 \pm 0.9$ & $39.20 \pm 0.1$ & $39.60^{\mathrm{a}} \pm 0.11$ & $27^{\mathrm{a}} \pm 0.5$ & $39.30^{\mathrm{a}} \pm 0.02$ & $38.37^{\mathrm{a}} \pm 0.09$ & $31^{\mathrm{a}} \pm 0.21$ \\
\hline $\mathrm{Cr}$ & $38.50^{\mathrm{e}} \pm 0.05$ & $37.98^{b} \pm 0.03$ & $22 \pm 0.9$ & $38.88 \pm 0.03$ & $38.57^{\mathrm{b}} \pm 0.11$ & $27^{\mathrm{a}} \pm 0.5$ & $39.43^{\mathrm{a}} \pm 0.02$ & $38.46^{\mathrm{a}} \pm 0.03$ & $31^{\mathrm{a}} \pm 0.21$ \\
\hline Se-E & $38.65^{\mathrm{de}} \pm 0.03$ & $37.75^{c} \pm 0.09$ & $22 \pm 0.4$ & $38.70 \pm 0.13$ & $38.37^{\mathrm{b}} \pm 0.07$ & $25^{\mathrm{b}} \pm 0.3$ & $39.45^{\mathrm{a}} \pm 0.05$ & $38.03^{\mathrm{b}} \pm 0.10$ & $26^{\mathrm{b}} \pm 0.37$ \\
\hline P-value & 0.0001 & 0.0001 & 0.085 & 0.065 & 0.016 & 0.0001 & 0.0001 & 0.0001 & 0.0001 \\
\hline
\end{tabular}

Means with different superscripts (A, B and $\mathrm{C}$ or $\mathrm{a}, \mathrm{b}, \mathrm{c}, \ldots)$ in the same column are significantly different at $(\mathrm{P}<0.05)$.

$\mathrm{Cr}=$ chromium, $\mathrm{Se}-\mathrm{E}=$ Selenium + Vitamin-E. 
Table 3. Means $( \pm \mathrm{SE})$ for factors affecting rectal temperature, skin temperature $\left({ }^{\circ} \mathrm{C}\right)$ and respiration rate (breathes/min) of does during postpartum period.

\begin{tabular}{|c|c|c|c|c|c|c|c|c|c|}
\hline \multirow{3}{*}{ Items } & \multicolumn{9}{|c|}{ Postpartum period } \\
\hline & \multicolumn{3}{|c|}{ 15-day PP } & \multicolumn{3}{|c|}{ 30-day PP } & \multicolumn{3}{|c|}{ 45-day PP } \\
\hline & $\mathrm{RT}$ & $\mathrm{ST}$ & $\mathrm{RR}$ & $\mathrm{RT}$ & ST & RR & $\mathrm{RT}$ & ST & $\mathrm{RR}$ \\
\hline \multicolumn{10}{|l|}{ Season $(S)$} \\
\hline Mild & $38.62 \pm 0.09$ & $37.64 \pm 0.11$ & $28 \pm 0.59$ & $39.38 \pm 0.07$ & $38.25 \pm 0.07$ & $30 \pm 0.45$ & $38.08 \pm 0.07$ & $38.0 \pm 0.07$ & $28 \pm 0.49$ \\
\hline Hot & $39.29 \pm 0.04$ & $37.86 \pm 0.10$ & $26 \pm 0.79$ & $39.01 \pm 0.04$ & $38.22 \pm 0.09$ & $23 \pm 0.68$ & $39.39 \pm 0.03$ & $38.32 \pm 0.05$ & $26 \pm 0.33$ \\
\hline$P$ - value & 0.0001 & 0.127 & 0.0001 & 0.0001 & 0.709 & 0.0001 & 0.0001 & 0.0001 & 0.0001 \\
\hline \multicolumn{10}{|c|}{ Treatments (T) } \\
\hline Control & $38.89 \pm 0.10$ & $37.74^{\mathrm{AB}} \pm 0.13$ & $29^{\mathrm{A}} \pm 0.49$ & $39.40^{\mathrm{A}} \pm 0.06$ & $38.40^{\mathrm{A}} \pm 0.12$ & $30^{\mathrm{A}} \pm 0.61$ & $39.29^{\mathrm{A}} \pm 0.07$ & $38.38^{\mathrm{A}} \pm 0.01$ & $30^{\mathrm{A}} \pm 0.55$ \\
\hline $\mathrm{Cr}$ & $38.90 \pm 0.10$ & $37.53^{\mathrm{B}} \pm 0.12$ & $27^{\mathrm{B}} \pm 0.91$ & $39.05^{\mathrm{B}} \pm 0.06$ & $38.41^{\mathrm{A}} \pm 0.06$ & $25^{\mathrm{B}} \pm 1.0$ & $38.86^{\mathrm{B}} \pm 0.12$ & $37.87^{\mathrm{B}} \pm 0.08$ & $26^{\mathrm{B}} \pm 0.25$ \\
\hline Se-E & $39.08 \pm 0.12$ & $37.99^{\mathrm{A}} \pm 0.13$ & $24^{\mathrm{C}} \pm 0.84$ & $39.15^{\mathrm{B}} \pm 0.09$ & $37.89^{\mathrm{B}} \pm 0.10$ & $24^{\mathrm{B}} \pm 0.9$ & $39.20^{\mathrm{A}} \pm 0.04$ & $38.21^{\mathrm{A}} \pm 0.07$ & $26^{\mathrm{B}} \pm 0.42$ \\
\hline P-value & 0.249 & 0.032 & 0.0001 & 0.0001 & 0.0001 & 0.0001 & 0.0001 & 0.0001 & 0.0001 \\
\hline \multicolumn{10}{|l|}{$\mathbf{S}^{*} \mathbf{T}$} \\
\hline \multicolumn{10}{|l|}{ Mild } \\
\hline Control & $38.38 \pm 0.14$ & $37.40 \pm 0.16$ & $30^{\mathrm{a}} \pm 0.49$ & $39.60^{\mathrm{a}} \pm 0.08$ & $38.10^{\mathrm{c}} \pm 0.17$ & $31^{\mathrm{a}} \pm 1.1$ & $38.97^{\mathrm{d}} \pm 0.07$ & $38.18^{\mathrm{b}} \pm 0.42$ & $32^{\mathrm{a}} \pm 0.42$ \\
\hline $\mathrm{Cr}$ & $38.50 \pm 0.18$ & $37.55 \pm 0.20$ & $26^{\mathrm{b}} \pm 1.20$ & $39.00^{\mathrm{b}} \pm 0.13$ & $38.33^{\mathrm{bc}} \pm 0.09$ & $30^{\mathrm{ab}} \pm 0.65$ & $38.35^{\mathrm{e}} \pm 0.12$ & $37.60^{c} \pm 0.10$ & $26^{c} \pm 0.39$ \\
\hline Se-E & $38.83 \pm 0.15$ & $37.98 \pm 0.18$ & $28^{\mathrm{ab}} \pm 0.13$ & $39.56^{\mathrm{a}} \pm 0.06$ & $38.33^{b c} \pm 0.08$ & $29^{b} \pm 0.25$ & $39.10^{\mathrm{cd}} \pm 0.08$ & $38.23^{\mathrm{b}} \pm 0.10$ & $27^{\mathrm{bc}} \pm 0.32$ \\
\hline \multicolumn{10}{|l|}{ Hot } \\
\hline Control & $39.25 \pm 0.03$ & $38.08 \pm 0.14$ & $28^{\mathrm{ab}} \pm 0.44$ & $39.20^{\mathrm{b}} \pm 0.03$ & $38.70^{\mathrm{a}} \pm 0.03$ & $29^{b} \pm 0.15$ & $39.60^{\mathrm{a}} \pm 0.03$ & $38.60^{\mathrm{a}} \pm 0.45$ & $28^{b} \pm 0.45$ \\
\hline $\mathrm{Cr}$ & $39.30 \pm 0.06$ & $37.50 \pm 0.13$ & $29^{\mathrm{a}} \pm 1.20$ & $39.10^{\mathrm{b}} \pm 0.02$ & $38.50^{\mathrm{ab}} \pm 0.09$ & $21^{\mathrm{c}} \pm 0.57$ & $39.37^{\mathrm{b}} \pm 0.13$ & $38.15^{\mathrm{b}} \pm 0.08$ & $27^{\mathrm{bc}} \pm 0.25$ \\
\hline Se-E & $39.33 \pm 0.10$ & $38.00 \pm 0.18$ & $20^{\mathrm{c}} \pm 0.43$ & $38.72^{\mathrm{c}} \pm 0.05$ & $37.46^{\mathrm{d}} \pm 0.06$ & $20^{c} \pm 0.21$ & $39.20^{\mathrm{bc}} \pm 0.02$ & $38.2^{\mathrm{b}} \pm 0.10$ & $24^{\mathrm{d}} \pm 0.42$ \\
\hline$P$ - value & 0.45 & 0.075 & 0.0001 & 0.0001 & 0.0001 & 0.0001 & 0.0001 & 0.003 & 0.0001 \\
\hline
\end{tabular}

Means with different superscript $(\mathrm{A}, \mathrm{B}$ and $\mathrm{C}$ or $\mathrm{a}, \mathrm{b}, \mathrm{c}, \ldots)$ in the same column are significantly different at $(\mathrm{P}<0.05)$.

$\mathrm{Cr}=$ chromium, $\mathrm{Se}-\mathrm{E}=$ Selenium + Vitamin-E. 


\section{References}

Abd El-Monem, U. M. and Abd El-Hamid, A. A., 2008. Effect of chromium picolinate supplementation on growth performance, carcass traits, biochemical parameters and blood constituents of growing lambs under the summer Egyptian conditions. Egyptian J. of Sheep and Goat Sciences (Special Issue, $2^{\text {nd }}$ Inter. Sci. Conf. on SR Production, 2008), 3(1): 95 - 104.

Abdulaziz, M. A., 2006. Effect of heat stress and supplemental chromium on thermo-respiratory responses, and some hematological and metabolic parameters and transaminases profile in ewes. University of Aden Journal of Natural and Applied Sciences 10(1): 31-40.

Alam, M. M., Hashem, M. A., Rahman, M. M., Hossain, M. M., Haque, M. R., Sobhan, Z. and Islam, M. S., 2011. Effect of heat stress on behavior, physiological and blood parameters of goat. Progress. Agric. 22(1 \& 2): $37-45$.

Alhidary, I. A., Shini, S., Al Jassim, R. A. M. and Gaughan, J. B., 2012. Effect of various doses of injected selenium on performance and physiological responses of sheep to heat load. J. Anim. Sci., 90:2988-2994.

AL-Zafry, S. R. and Medan, M. S., 2012. Effects of vitamin $\mathrm{E}$ and selenium complex on heatstressed rabbits. SCVMJ, 17(2): 129-138.

Anderson R. A., 1994. Stress effects on chromium nutrition of humans and farm animals. In: Proceedings of Alltech's $10^{\text {th }}$ Annual Symposium, Biotechnology in the Feed Industry, Lyons P., Jacques K. A. (eds.), Nottingham University Press, UK, 267-274.

An-Qiang, L., Zhi-Sheng, W. and An-Guo, Z., 2009. Effect of chromium picolinate supplementation on early lactation performance, rectal temperatures, respiration rates and plasma biochemical response of Holstein cows under heat stress. Pak. J. Nutr., 8 (7): 940-945.

Bernabucci, U., Ronchi, B., Lacetera, N. and Nardone, A., 2002. Markers of oxidative status in plasma and erythrocytes of transition dairy cows during the hot season. J. Dairy Sci. 85:21732179.

Burke, N. C., Scaglia, G., Saker, K. E., Blodgett, D. J. and Swecker Jr. W. S., 2007. Influence of endophyte consumption and heat stress on intravaginal temperatures, plasma lipid oxidation, blood selenium, and glutathione redox of mononuclear cells in heifers grazing tall fescue. J. Anim. Sci. 85:2932-2940.

Chauhan, S. S., Celi, P., Leury, B. J., Clarke, I. J. and Dunshea, F. R. 2014. Dietary antioxidants at supranutritional doses improve oxidative status and reduce the negative effects of heat stress in sheep. J. Anim. Sci., 92:3364-3374.

Davis C.M., and Vincent J.B., 1997. Isolation and characterization of a biologically active chromium oligopeptide from bovine liver. Archives of Biochemistry and Biophysics, 339: 335-343.

Devendra, C., 1987. Goats. Ed. Johnson, H. P. In: Bioclimatology and the Adaptation of Livestock. Elsevier Publication Holland. pp. 16-77.

Duncan, D.B., 1955. Multiple range and multiple Ftest. Biometrics, 11:1-42.

El-Shahat, K. H. and Abdel Monem, U. M., 2011. Effects of dietary supplementation with vitamin $\mathrm{e}$ and /or selenium on metabolic and reproductive performance of Egyptian Baladi ewes under subtropical conditions. World Appl. Sci. J., 12 (9): 1492-1499.

Fahmy, S., 1994. Effect of crossing Romanov with Rahmani sheep on some physiological and productive performance. M. Sc. thesis. Fac. Agric. Al-Azhar Univ., Cairo, Egypt.

Habeeb, A. A. M., Marai, I. F. M. and Kamal, T. H., 1992. Heat stress. In: C. Philips and D. Piggens, editors, Farm animals and the environment. CAB International, Wallingford, UK. p. 27-47.

Hansen, J. P., 2009. Effects of heat stress on mammalian reproduction. Phil.Trans.R. Soc. B., 364: 3341-3350.

Jordan, E. R., 2003. Effects of heat stress on reproduction. J. Dairy Sci. 86: E. Suppl.: 104-114.

Khalifa, H. H.; El-Sherbiny, A. A. and AbdelKhalik, T. M. M., 2000. Effect of exposure to solar radiation on some adaptive physiological mechanisms of Egyptian goats. Proc. Conf. Anim. Prod. In the 12st Century, Sakha, 18-20 April 2000, pp. 297-305.

Kobeisy, M. A., Soliman, I. A. and Abdulaziz, M. A., 2004. Influence of chromium supplementation on thermo-respiration response and some blood parameters of sheep exposed to exercise under direct sunlight. Egyp. J. Anim. Prod., 41:405-410.

Lacetera, N., Tuscia, D. L., Ronchi, B., Bernabucci, U., Scalia, D. and Nardone, A., 2002. Periparturient immune response in heatstressed dairy cows fed supplemental chromium tripicolinate. $15^{\text {th }}$ Conf. on Biometeorology/Aerobiology and $16^{\text {th }}$ International Congress of Biometeorology.

Lien, T. F., Horng, Y. M. and Yang, K. H., 1999. Performance, serum characteristics, carcase traits and lipid metabolism of broilers as affected by supplement of chromium picolinate. Brit. Poultry Sci., 40: 357-363.

Liu, F., Jeremy, J., Cottrell, J. J., Wijesiriwardana, D., Kelly, W. F., Celi, P., Leury, J. B., and Dunshea, R.F., 2015. Chromium supplementation alleviates heat stress in growing pigs. J. Dairy Sci., 98, Suppl. 2.

Marai, I.F.M., Bahgat, L.B., Shalaby, T.H. and Abdel-Hafez, M.A., 2000. Fattening performance, some behavioural traits and physiological reactions of male lambs fed 
concentrates mixture alone with or without natural clay, under hot summer of Egypt. Ann. Arid Zone, 39 (4): 449-460.

Marai, I. F. M., Daader, A. M., Abdel-Samee, A. M. and Ibrahim, H., 1997. Winter and summer effects and their amelioration on lactating Friesian and Holstein cows maintained under Egyptian conditions. In: Proceedings of International Conference on Animal, Poultry, Rabbits and Fish Production and Health, Cairo, Egypt.

Marai, I. F. M., El-Darawany, A. F. and AbdelHafez, M. A. M., 2007. Physiological traits as affected by heat stress in sheep. A review. Small rumin. Res., 71: 1 - 12.

Meschy, F., 2000. Recent progress in the assessment of mineral requirements of goats. Livest. Prod. Sci., 64:9-14.

Moonsie-Shageer, S. and Mowat, D.N., 1993. Effect of level of supplemental chromium on performance, serum constituents, and immune status of stressed feeder calves. Anim. Sci., 71 (1): 232-238.

Mowat, D.N., 1994. Organic chromium: a new nutrient for stressed animals. In: Proceedings of Alltech's 10th Annual Symposium, Biotechnology in the Feed Industry, Lyons P., Jacques K. A. (eds.), Nottingham University Press, UK, 275-282.

NRC., 2007. Nutrient Requirements of Small Ruminants: Sheep, Goats, Cervids, and New World Camelids. Natl. Acad. Press, Washington, DC.

Otoikhian, C.S.O., Orheruata, J.A., Imasuen, J.A. and Akporhuarho, O.P., 2009. Physiological response of local (West African Dwarf) and adapted switndzerla (White Bornu) goat breed to varied climatic conditions in South- South Nigeria. African J General Agric. 5:1-6.

Phulia, S.K., Upadhyay, R.C., Jindal, S.K. and Misra, R.P., 2010. Alteration in surface body temperature and physical responses in Sirohi goats during day time in summer season. Ind. J. Anim. Sci. 80: 340-342.

Sahin, K., Küçük, O. and Sahin, N., 2001. Effects of dietary chromium picolinate supplementation on performance and plasma concentrations of insulin and corticosterone in laying hens under low ambient temperature. J. Anim. Physiol. Anim. Nutrt., 85: 142-147.

SAS, 1998. Statistical analysis system user's guide, Release 6.0 ed. $4^{\text {th }}$ edition, SAS Institute Inc. Cary, NC, USA.

Sharma, S., Ramesh, K., Hyder, I., Uniyal, S. and Yadav, V.P., 2013. Effect of melatonin administration on thyroid hormones, cortisol and expression profile of heat shock proteins in goats (Capra hircus) exposed to heat stress. Small Rumin. Res. 112: 216-223.

Shebaita, M. K. and El-Banna, I. M., 1982. Heat load and heat dissipation in sheep and goats under environmental heat stress. Pp. 459-469 in Proc. 6th Int. Conf. Anim. Poult. Prod., Univ. Zagazig, Zagazig, Egypt.

Slee, J., 1966. Variation in the responses of shorn sheep to cold exposure. Anim. Prod. 8: 425-434.

Williams, J. E., Myers, J. L., Richard, C. R. and Grebing, S. E., 1994. Influence of yeast culture, chromium, and thermal challenge on $\mathrm{N}$ and mineral balance in lambs. J. Anim. Sci.72 (Suppl. 2):86.

Yari, M., Nikkhah, A., Alikhani, M., Khorvash, M., Rahmani, H., and Ghorbani, G. R., 2010. Physiological calf responses to increased chromium supply in summer. J. Dairy Sci. 93:4111-4120.

Zeidan, A. E., Hanna, M. F., Hamouda, T.A. and Seleem, T. S., 2001. Some productive and reproductive traits of male rabbits as affected by vitamin $\mathrm{E}$ and selenium administration under hot climatic conditions. Egyp. J. nutr. and feeds. 4:897-908. 


\title{
تخفيف الإستجابات الحرارية لإناث الماعز البلاي بإضافة الكروميوم والسيلينيوم-هـ في المناطق شبه الحارة.
}

\author{
شريف يوسف عيد'، أ.د. عبدالكريم إبراهيم محمد السيد² ، أ.د. حسن أحمد فرظي 1 و د. أكرم عبد الستار الطريانى1 \\ 1. قسم التطبيقات البيولوجبة - شعبة نطيبقات النظائر المشعة - مركز البحوث النووية - هيئة الطاقة الذرية

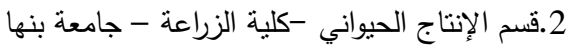

خلاصة

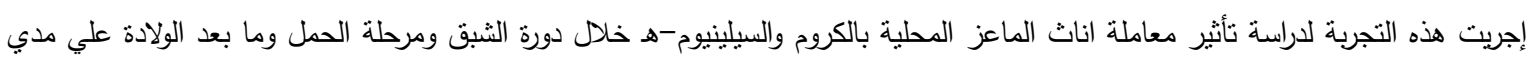

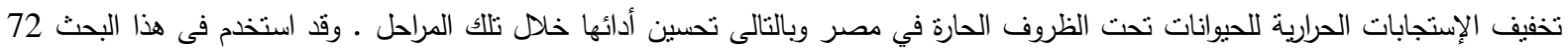

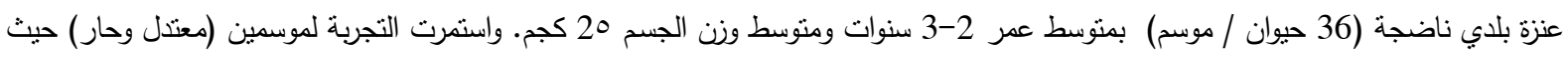

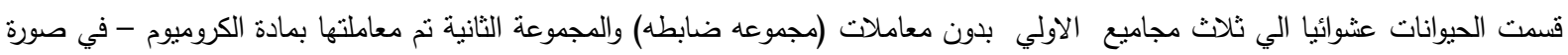

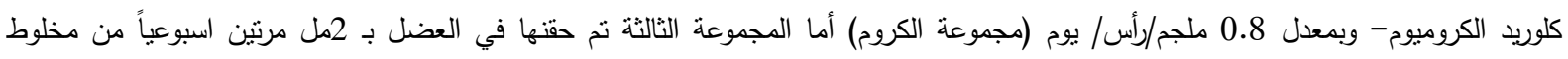

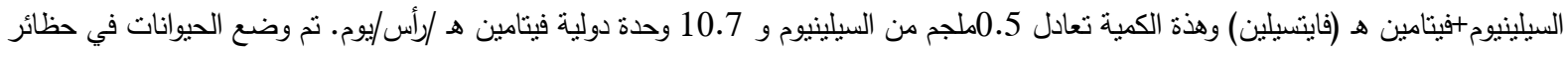

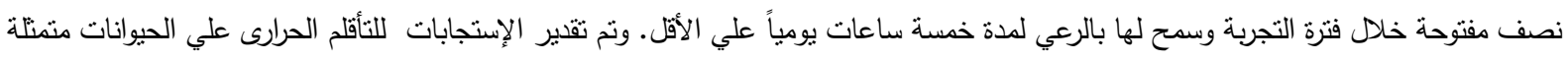
في درجة حرارة المستقيم والجلد ومعدل التنفس.

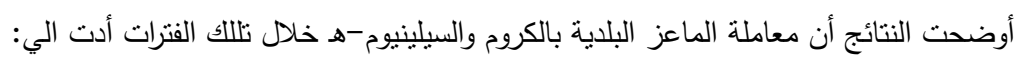

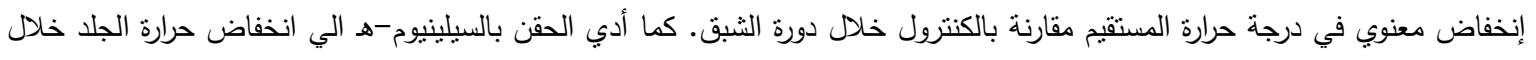

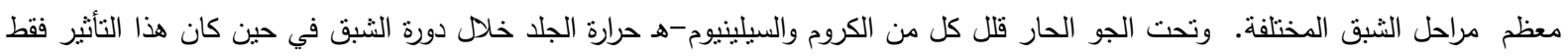
للليلينوم علي معدل التنفس دون الكروم.

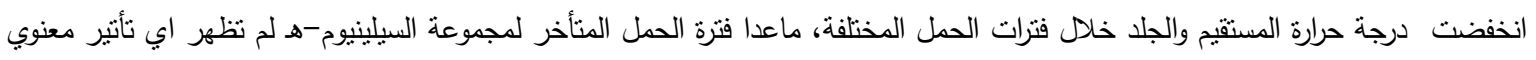

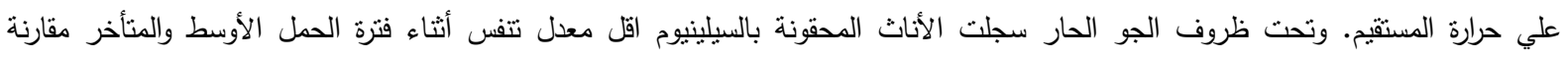

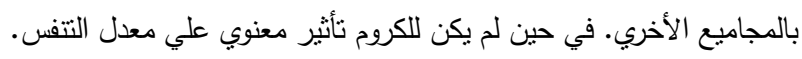

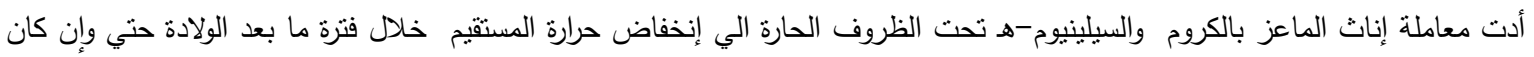

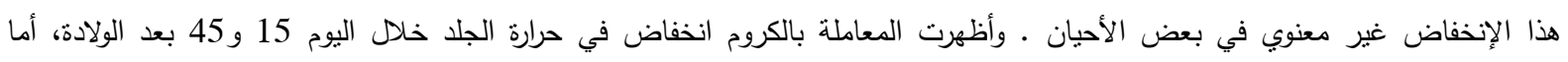

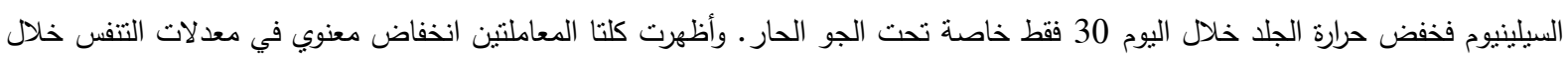
فترة ما بعد الولادة حيث اظهر السيلينيوم-هـ هذا الانخفاض تحت الجئ الجو الحار دون الكروم. 